\title{
Indicele de clearance pulmonar - parametru de evaluare a funcției pulmonare la copiii cu fibroză chistică
}

\author{
Mihaela Dediu', Ioana Mihaiela Ciucă', Voicu Tudorache², Liviu Laurențiu Pop ${ }^{1}$ \\ ${ }^{1}$ Departamentul Pediatrie, Universitatea de Medicină şi Farmacie „Victor Babeş“, Timişoara, România \\ 2Departamentul Pneumologie, Universitatea de Medicină şi Farmacie „Victor Babeş“, \\ Timişoara, România
}

\begin{abstract}
REZUMAT
FC este o boală polimorfă a cărei evoluţie este marcată de patologia pulmonară. Obstrucţia distală, demonstrată anatomopatologic, poate fi evidenţiată prin spirometrie, care poate fi utilizată doar la anumite categorii de vârstă. Detectarea cât mai precoce a obstrucţiei, cu instituirea terapiei adecvate, este esenţială pentru prelungirea speranţei de viaţă a acestor pacienţi. Un parametru promiţător a fost descris relativ recent, indicele de clearance pulmonar, obţinut prin tehnica spălărilor multiple. Multiple studii au demonstrat eficienţa acestuia şi corelaţia cu modificările morfologice pulmonare subliniind faptul că ICP este un parametru fezabil şi specific pentru a detecta de la vârstă mică modificările pulmonare la pacientul cu FC. În concluzie, indicele de clearance pulmonar este un parametru specific pentru detectarea pneumopatiei din fibroza chistică şi reprezintă actualmente modalitatea standard de monitorizare a pneumopatiei din FC, urmând a fi utilizat în practica curentă a centrelor specializate în FC.
\end{abstract}

Cuvinte cheie: indice de clearance pulmonar, fibroză chistică, funcţie pulmonară

\section{INTRODUCERE}

Fibroza chistică (FC), cea mai frecventă afecţiune monogenică a populaţiei caucaziene, este caracterizată clinic de un tablou impresionant, cu afectare pulmonară şi gastrointestinală (1). Cu toate că speranţa de viaţă a pacienţilor cu FC a crescut în ultimii ani, rata mortalităţii este aproape constantă în special din cauză degradării progresive a funcţiei pulmonare $(1,2)$.

Deşi în prezent se cunoaşte baza moleculară a acestei maladii (gena CFTR), cercetările efectuate până în prezent nu au găsit o terapie curabilă eficientă, astfel încât prognosticul şi evoluţia bolii sunt dictate de statusul pulmonar (2).

Mutaţiile genei reglatoare a conductanţei transmembranare a fibrozei chistice (CFTR) determină scăderea cantităţii de apă şi creşterea vâscozităţii mucusului prin transportul deficitar de $\mathrm{Cl}^{-}$şi $\mathrm{HCO}_{3}$
(2). Stagnarea mucusului reprezintă un mediu favorabil pentru dezvoltarea infecţiilor virale şi bacteriene, a inflamaţiei cronice progresive, apariţia bronşiectaziilor şi alterarea funcţiei pulmonare $(2,3)$.

\section{BOALA PULMONARĂ DIN FIBROZA CHISTICĂ}

Există încă numeroase dezbateri în ceea ce priveşte când şi cum apar primele modificări pulmonare, în special din cauza naturii heterogene a afectării pulmonare în cadrul acestei populaţii. Modelele animale sugerează că anomaliile structurale ale plămânului din FC pot apărea in utero (1). Se consideră că boala începe încă din momentul concepţiei, când spermatozoidul fecundează ovulul pentru a crea un embrion cu două mutaţii CFTR patologice (2). 
Evaluarea funcţiei pulmonare este o parte esenţială a îngrijirii clinice pentru detectarea modificărilor la nivel pulmonar şi instituirea unui tratament adecvat $(1,2)$. Obstrucția căilor respiratorii este progresivă, fapt demonstrat de spirometrii, dar funcţia pulmonară poate fi conservată în parametri normali, atât în perioada copilăriei, cât şi la maturitate (3),(4), prin îngrijire multidisciplinară.

Evaluarea funcţională a statusului pulmonar nu este reprezentativă pentru deteriorarea structurală sau anatomică a plămânului. Există dovezi importante ce demonstrează că progresia bronşiectaziilor poate să nu fie detectată de spirometrie timp de mulţi ani (5), în timp ce $30 \%$ dintre pacienţii cu FC cu parametri spirometrici normali au deja daune structurale la tomografia computerizată de înaltă rezoluţie $(6,7)$.

\section{INDICELE DE CLEARANCE PULMONAR}

$\mathrm{Au}$ fost propuse numeroase teste funcţionale pulmonare pentru copii conştienţi, cu vârste preşcolare. Prin acestea se numără: spirometria standard, oscilometria forţată, rezistenţa la flux a căilor aeriene cu ajutorul pletismografului, capacitatea reziduală funcţională prin tehnicile de diluţie cu gaz şi indicele de amestec gazos (8).

La pacienţii cu fibroză chistică este utilizat în prezent în centrele specializate indicele de clearance pulmonar (ICP), un parametru ce reflectă gradul de omogenitate al plămânului şi este măsurat prin tehnica spălărilor multiple (multiple breath washout) cu amestec de gaz (N2, O2, H2) $(7,8,9)$.

Studii recente au arătat că ICP este un parametru fezabil şi specific pentru a detecta atât la vârsta preşcolară şi şcolară, cât şi la cea adultă modificări pulmonare la pacientul cu FC, fiind mai uşor de obţinut, chiar şi la copiii mai mici ce nu cooperează pentru efectuarea spirometriei, deoarece se determină în timpul respiraţiei de tip tidal $(7,9)$.

Procesele patologice ce afectează căile respiratorii periferice vor determina o creştere a heterogenităţii difuziei pulmonare (8). Inegalitatea ventilaţiei afectează eficienţa globală a amestecului de gaze la nivel pulmonar şi poate fi măsurată prin urmărirea eliminării unui gaz martor în timpul respiraţiei de tip tidal. În prezenţa unui proces patologic, acest proces de eliminare va avea o durată mai lungă, necesitând un număr mai mare de respiraţii (9).

Orice test de spălare a unui gaz cuprinde o fază de dispersie şi o fază de eliminare a gazului respectiv (7). În cazul gazelor inerte extrinseci sau al gazelor nonreziduale pulmonare, în timpul fazei de dispersie, gazul marker este distribuit la o concen- traţie cunoscută (10). Procesul de dispersie este încheiat în momentul în care concentraţia gazului expirat atinge concentraţia gazului dispersat. În cazul gazelor inerte intrinseci, nu există faza de dispersie, fiind necesare doar câteva respiraţii de tip tidal pentru a ne asigura că este stabilă $(80 \%)$ concentraţia de azot (N2) (11).

Indicele de clearance pulmonar este un parametru ce se obţine în timpul fazei de spălare. În această fază, subiectul inspiră un gaz care nu conţine gazul marker (aerul din cameră pentru sulfura de hexaflor, $100 \%$ O2 pentru N2) (10). Gazul marker trebuie să fie inert şi să nu fie absorbit sau excretat în organism. Cu fiecare respiraţie succesivă a spălării, se înregistrează o scădere a concentraţiei maxime a markerului expirat $(7,9,11)$.

ICP este un parametru numeric ce reprezintă numărul de spălări/respiraţii de tip tidal necesare pentru a elimina o cantitate de N2 până la valoarea minimă acceptată (8). Cu cât gradul de afectare pulmonară este mai avansat, pacientul necesitând o perioadă mai lungă pentru a atinge nivelul minim al concentraţiei de $\mathrm{N} 2$ acceptate, cu atât valoarea acestuia va fi mai mare $(8,9)$. ICP scade în timpul perioadei de sugar şi prima copilărie, se menţine ulterior constant până în perioada de adult şi creşte uşor la bătrâneţe (10). Valoarea ICP nu se modifică odată cu talia şi nu este dependentă de sexul pacientului, acest lucru fiind deosebit de important în special în studiile longitudinale efectuate la copii (8).

În prezent, determinarea ICP este o tehnică efectuată în puţine centre specializate şi, de cele mai multe ori, este folosită în scop ştiinţific (11).

\section{AVANTAJE Şı DEZAVANTAJE}

Sensibilitatea deosebită a ICP la boala pulmonară din $\mathrm{FC}$ poate evidenţia patologia pulmonară subiacentă, care este una dintre inflamaţiile şi obstrucţiile inegale ale căilor respiratorii mici (9), acest lucru fiind important în detectarea precoce a leziunilor pulmonare de la nivelul căilor aeriene mici, fiind important şi pentru stabilirea unei corelaţii între modificarile structurale şi cele funcţionale (12).

Determinarea indicelui de clearance pulmonar este testul ideal pentru copii, datorită tehnicii relativ simple, ce necesită doar respiraţii de tip tidal, putând fi efectuat inclusiv de sugari $(13,14)$. Nu necesită cooperare şi nici sedare. Deşi sensibilitatea crescută a ICP îl face un test util pentru diagnosticul leziunilor pulmonare precoce, acest test nu aduce informaţii importante la pacienţii cunoscuţi cu 
leziuni obstructive severe (8). Determinarea ICP este cea mai bună modalitate de evaluare a funcţiei pulmonare la copilul mic şi sugar, cu o bună sensibilitate şi specificitate pentru pneumopatia din fibroza chistică $(9,10,11)$.

\section{INDICELE DE CLEARANCE PULMONAR ÎN PRACTICA MEDICALĂ}

Numeroase studii au demonstrat utilitatea ICP în depistarea alterării funcţiei pulmonare (14) mai uşor decât spirometria la copiii cu vârstă preşcolară (15) şi cei cu vârstă şcolară (16). Un studiu efectuat în Suedia, pe 142 pacienţi cu FC, privind evaluarea funcţiei pulmonare la aceştia, a demonstrat că valoarea ICP este prima care se modifică, înaintea $\mathrm{FEF}_{50 \%}$ şi a CVF, iar FEV1 este ultimul parametru care se modifică (17). Mai mult, acelaşi studiu a pus în evidenţă continuarea creşterii ICP, împreună cu hiperinflaţia pulmonară şi volumul de aer „captiv", după vârsta de 12 ani, când scorul $\mathrm{Z}$ al FEV rămâne constant.

De asemenea, indicele a fost raportat în studii care implică toate grupele de vârstă, de la sugari la adulţi $(13,18)$, acest lucru făcându-1 deosebit de potrivit pentru studiile de lungă durată. În fibroza chistică în mod special, există o necesitate crescută în ceea ce priveşte alegerea unor teste sensibile şi repetabile pentru intervenţiile terapeutice (19); de asemenea, ICP a fost propus ca indice de urmărit în viitoarele studii privind terapia genică din fibroza chistică (20).

Acest indice a fost utilizat şi în două studii clinice pentru a examina răspunsul clinic la terapia antibiotică intravenoasă la copiii cu CF, în timpul exacerbărilor pulmonare acute (18), fiind un parametru util şi precis pentru evaluarea rezultatului (22). Studiile au arătat o corelaţie foarte bună între neomogenitatea ventilatorului şi durata respiraţiei, expri- mată prin LCI, şi indicele tusei şi saturaţia nocturnă (23), arătând că, cu cât mai mult timp necesar pentru spălarea N2, cu atât mai pronunţate au fost episoadele de tuse şi desaturarea de noapte. Pentru o determinare corectă a ICL fiabile, ar putea fi necesare două tehnic acceptabile N2 MBW la copiii de şcoală pentru evaluarea ventilaţiei, deşi este nevoie de şi mai mult timp (24) pentru a obţine o fiabilitate şi o sensibilitate bună (25).

\section{CONCLUZII}

În concluzie, indicele clearance-ului pulmonar este un parametru specific pentru detectarea bolii pulmonare precoce în fibroza chistică, precum şi pentru monitorizarea acesteia, reprezentând în prezent parametrul standard pentru monitorizarea funcţiei pulmonare la copiii cu fibroză chistică, deoarece descoperirea primară a modificărilor pulmonare, urmată de îngrijire intensă şi adecvată, va prelungi speranţa vieţii copiilor cu CF. În prezent, ICP se foloseşte în principal în centrele specializate pentru CF, în ţara noastră la Centrul Naţional de Fibroză Chistică Timişoara, timp de 3 ani, şi va fi utilizat pe scară largă ca standard de aur pentru a fi utilizat în practica curentă a centrelor specializate de FC în viitorul apropiat. Indicele clearance-ului pulmonar este parametrul standard în cercetarea pulmonară CF şi utilitatea sa clinică a fost dovedită şi susţinută în mod clar de mai multe studii, atingând un obiectiv de decenii, care a solicitat o indicaţie consistentă, reproductibilă şi corectă de prognostic de fibroză chistică. LCI este un parametru folosit in evaluarea a diferite patologii respiratorii ce afectează mai ales căile respiratorii mici, iar utilizarea sa viitoare şi actuală va include nu doar fibroza chistică, ci şi astmul, wheezing-ul recurent, dischinezia ciliară primară şi alte boli respiratorii.

Conflict of interest: none declared Financial support: none declared

\section{BIBLIOGRAFIE}

1. Lahiri T et al. Clinical Practice Guidelines from the Cystic Fibrosis Foundation for Preschoolers with Cystic Fibrosis, Pediatrics. 2016 April; 137(4), 2015-1784

2. Suri R, Metcalfe $C$, Lees $B$ et al. Comparison of hypertonic saline and alternate-day or daily recombinant human deoxyribonuclease in children with cystic fibrosis: A randomised trial. Lancet. 2001; 358(9290):1316-21.

3. Marshall BC, Nelson EC. Accelerating implementation of biomedical research advances: Critical elements of a successful 10 year Cystic Fibrosis Foundation healthcare delivery improvement initiative. BMJ Qual Saf. 2014;23(SUPPL1).

4. CFF. Annual Report 2012. Cyst Fibros Found Patient Regist. 2012.

5. Mott LS, Park J, Murray CP et al. Progression of early structural lung disease in young children with cystic fibrosis assessed using CT. Thorax. 2012;67(6):509-16.

6. Lindblad A, Rubin L, Hop WCJ et al. Progression of lung disease on computed tomography and pulmonary function tests in children and adults with cystic fibrosis. Thorax. 2006;61(April 2004):80-5.

7. Gustafsson PM, De Jong PA, Tiddens HAWM et al. Multiple-breath inert gas washout and spirometry versus structural lung disease in cystic fibrosis. Thorax. 2008;63(2):129-34.

8. Beydon N, Davis SD, Lombardi E, Allen JL, Arets HG, Aurora P et al. An official American Thoracic Society/European Respiratory Society statement: Pulmonary function testing in preschool children. Am J Respir Crit Care Med. Jun 15 2007; 175: 1304-1345

9. Horsley A. Lung clearance index in the assessment of airways disease. Respir Med. 2009;103(6):793-9.

10. Subbarao P, Milla C, Aurora P et al. Multiple-breath washout as a lung function test in cystic fibrosis: A cystic fibrosis foundation workshop report. Ann Am Thorac Soc. 2015;12(6):932-9. 
11. Lum S, Stocks J., Stanojevic S. et al. Age and height dependence of lung clearance index and functional residual capacity. Eur Respir J. 2013;41(6):1371-7.

12. Ciuca IM, Dediu M, Tamas $L$ et al. Lung ultrasound score and the relation with lung clearance index, Journal of Cystic Fibrosis, Volume 17, Supplement 3, 2018, Pages S11-S12, ISSN 1569-1993

13. Bedrossian CWM, Donald Greenberg S, Singer DB et al. The Lung in Cystic Fibrosis: A Quantitative Study Including Prevalence of Pathologic Findings Among Different Age Groups. Hum Pathol. 1976;7(2):195-204.

14. Lum S, Gustafsson P, Ljungberg $\mathrm{H}$ et al. Early detection of cystic fibrosis lung disease: Multiple-breath washout versus raised volume tests. Thorax. 2007;62(4):341-7.

15. Aurora P, Bush A, Gustafsson P et al. Multiple-breath washout as a marker of lung disease in preschool children with cystic fibrosis. Am J Respir Crit Care Med. 2005;171(3):249-56.

16. Gustafsson PM, Aurora P, Lindblad A. Evaluation of ventilation maldistribution as an early indicator of lung disease in children with cystic fibrosis. Eur Respir J. 2003;22(6):972-9.

17. Ciuca IM, Dediu M, Vlad D et al. Lung Clearance Index and vitamin D. Journal of Cystic Fibrosis, Volume 17, Supplement 3, 2018, Page S94

18. Kraemer R, Blum A, Schibler A et al. Ventilation inhomogeneities in relation to standard lung function in patients with cystic fibrosis. Am J Respir Crit Care Med. 2005;171(4):371-8.
19. Horsley AR, Gustafsson PM, Macleod KA et al. Lung clearance index is a sensitive, repeatable and practical measure of airways disease in adults with cystic fibrosis. Thorax. 2008;63(2):135-40.

20. Rosenfeld M. An overview of endpoints for cystic fibrosis clinical trials: One size does not fit all. Proc Am Thorac Soc. 2007;4(4):299-301.

21. Davies JC, Cunningham S, Alton EWFW et al. Lung clearance index in CF: A sensitive marker of lung disease severity. Thorax. 2008;63(2):96-7.

22. Robinson PD et al. Using index of ventilation to assess response to treatment for acute pulmonary exacerbation in children with cystic fibrosis. Pediatr Pulmonol. 2009;44(8):733-42.

23. Bakker EM et al. Determining presence of lung disease in young children with cystic fibrosis: Lung clearance index, oxygen saturation and cough frequency. Journal of Cystic Fibrosis, Volume 11(3) 223 230

24. Green, Kent \& S Ejlertsen, Jacob \& Ring, Astrid \& Buchvald, Frederik \& Kongstad, Thomas \& Kobbernagel, Helene \& M Gustafsson, Per \& Nielsen, Kim. Abbreviation Modalities of Nitrogen Multiple-Breath Washout Tests in School Children With Obstructed Lung Disease. Pediatric Pulmonology (2015). 51. 10.1002/ppul.23339.

25. Horsley AR, Macleod KA, Robson AG, Lenney J, Bell NJ, Cunningham $S$ et al. Effects of cystic fibrosis lung disease on gas mixing indices derived from alveolar slope analysis. Respir Physiol Neurobiol. 2008;162(3):197-203 